\title{
ADOPTION OF BIOSECURITY MEASURES BY LAYER SMALLHOLDERS
}

\author{
V. S. Lestari, S. N. Sirajuddin and K. Kasim \\ Faculty of Animal Husbandry, Hasanuddin University \\ Jl. Perintis Kemerdekaan, KM 10, Makassar-90245, South Sulawesi - Indonesia \\ Corresponding E-mail: veronicasrilestari@yahoo.co.id \\ Received.November 01, 2011; Accepted November, 30, 2011
}

\begin{abstract}
ABSTRAK
Terdapat indikasi bahwa kesadaran peternak ayam ras petelur terhadap biosekuriti masih rendah. Makalah ini bertujuan untuk menentukan tingkat adopsi peternak ayam ras petelur di Sulawesi Selatan dalam berbagai tindakan biosekuriti. Kabupaten Sidenreng Rappang (Sidrap) dipilih sebagai lokasi penelitian karena terkenal sebagai pusat peternakan ayam ras petelur. Jumlah sampel adalah 60 responden. Sampel dipilih secara acak dari dua kecamatan yang paling banyak peternaknya yaitu Baranti dan Maritengae. Data dikumpulkan menggunakan kuesioner terstruktur dan wawancara. Data ditabulasi dan dianalisis menggunakan metode skoring status biosekuriti. Status biosekuriti digunakan untuk mengetahui tingkat adopsi biosekuriti. Status biosekuriti diperoleh berdasarkan penerapan tindakan biosekuriti yang terdiri dari 9 tahap yaitu: input peternakan, lalu lintas ke peternakan, jarak dari sumber penyakit dengan kandang, keadaan peternakan, biosekuriti pada pagar peternakan, biosekuriti antara pagar dan kandang, biosekuriti di pintu kandang, lalu lintas dalam kandang dan kerentanan terhadap penyakit. Berdasarkan indeks adopsi, hasil penelitian menunjukan bahwa adopsi biosekuriti pada peternak ayam ras petelur di Sulawesi Selatan diklasifikasikan sebagai parsial adopter.
\end{abstract}

Kata kunci: adopsi biosekuriti, peternak, ayam ras petelur

\begin{abstract}
It was indicated that layer smallholders awareness of biosecurity was low. This paper aimed to determine the level of adoption within the South Sulawesi layer smallholders of a range of standard biosecurity measures. Sidenreng Rappang (Sidrap) regency was chosen as a location of the research, because it was famous as a central of layer smallholders. Total sample was 60 respondents. The sample was chosen through random sampling from two districts which were the most populous of layer smallholders, namely Baranti and Maritengae. Data were collected using structured questionnaires and depth-interview. The data were tabulated and analysed using a simple method of scoring with regard to their biosecurity status. The status of biosecurity was used to know the level of biosecurity adoption. Biosecurity status was obtained based on the adoption of biosecurity measures which consisted of 9 stages: farm inputs, traffic onto farms, distance from sources of pathogens to shed, exposure of farm, biosecurity at farm boundary, biosecurity between farm boundary and shed, biosecurity at the shed door, traffic into the shed and susceptibility of the flock. Using adoption index, this research revealed that biosecurity adoption of layer smallholders in South Sulawesi was classified into a "partial adopter".
\end{abstract}

Keywords: adoption of biosecurity, smallholder, layer

\section{INTRODUCTION}

Biosecurity is security from transmission of infectious diseases, parasites and pests. Biosecurity has focus on maintaining or improving the health status of animal and preventing the introduction of new disease pathogens by assessing all possible risks to animal health (Satyanarayana et al., 2008; Zavala, 2011; Australian Biosecurity Co-operative Research
Centre, 2009; Fraser et al., 2010; Iqbal, 2009; Dorea et al., 2010; Julien and Thomson, 2011; Fasina et al., 2011). Most animal health programs will increase their odds of success (Msoffe et al., 2009).

Biosecurity has three major components: isolation, traffic control and sanitation. Biosecurity should be increased to reduce disease outbreak. Biosecurity will not only maintain the good environment but also minimize infectious 
and zoonotic diseases and subsequently increase public health (Sharma, 2010).

Adoption is a process of receiving an innovation, hopefully there is a change in cognitive, affective, and psychomotoric to any body who get innovation from extension worker. Farmers need a different time to adopt an innovation. There are five of adoption stage: awareness, interest, evaluation, trial and error, and the last is adoption (Ban and Hawkins, 1999).

Sidenreng Rappang (Sidrap regency) is famous as the most populous of layer farms in South Sulawesi. Sidrap regency consists of 11 districts which supply meat and eggs to consumers in South Sulawesi. Total layer smallholders in Sidrap regency was 1,334 with the population 3,439,556 chickens (Dinas Peternakan Kabupaten Sidenreng Rappang, 2011). In 2005, Sidrap regency became one of six regencies in South Sulawesi which suffer from Avian influenza outbreak and affects to several loss from their layer farms (Kristanti, 2009). It is indicated that some layer smallholders do not aware with biosecurity measures in their farms.

The study was undertaken with the following objective to determine the level of adoption within the South Sulawesi layer smallholders of a range of standard biosecurity measures.

\section{MATERIALS AND METHODS}

This research was conducted for a month in May 2010. Sinreng Rappang (Sidrap) regency was choosen as a location of the research, because Sidrap regency was famous as a central of layer smallholders in South Sulawesi. Total sample was 60. The sample was choosen from two districts with the most populous layer smallholders, namely Maritengngae and Baranti which had total population of 601 layer farmers. Arikunto (2002) stated that $10 \%$ of the population could be used as a sample if the population was greater than 100 . Data were collected using structured questionnaires and depth-interview. The data were analyzed using a simple method of scoring with regard to their biosecurity status.

Layer smallholders biosecurity status was adopted from Patrick and Jubb (2010). A large number of biosecurity risks and biosecurity measures have been identified and combined into nine stages, namely: farm inputs, traffic onto farm, distance from source of pathogens to shed, exposure of farm, biosecurity at farm boundary, biosecurity between farm boundary and shed, biosecurity at the shed door, traffic into shed and susceptibility of flock. Farm biosecurity model was described in Figure 1.

\section{The farm biosecurity status score (FBSS)}

a.Scoring indicators

The first step in generating a FBSS was to score each individual biosecurity indicator. Actually there were 65 indicators. Most of the indicators have been allocated scores ranging from 1 to 3 (1 being low biosecurity, 2 being medium biosecurity and 3 being high biosecurity). The minimum score one could score was 0 and maximum score was 195.

\section{b. Scoring stages}

These individual biosecurity indicators can be grouped into the nine biosecurity stages (as defined in Figure 1). Each can be scored by summing the scores of the individual indicators in each stage. The score will be influenced by the number of indicators in the stage. This measure gave every indicator an equal value, and therefore, the stages with more indicators were intrinsically more important.

\section{c. Scoring farms}

A farm biosecurity score can be calculated by summing the stage scores (FBSS). The FBSS was the simplest method and makes no judgment with regard to the importance of each variable. It valued every individual risk variable equally.

\section{d. Adoption level}

The adoption level of the respondents was measured by making use of adoption index (Karthikeyan, 1994 in Rahman, 2007).

Adoption index $=($ Respondent total score $/$ Total possible score) $\mathrm{x} 100$

Depending upon the extent of adoption of biosecurity measures the respondents were categorized as follows: (1) Low adopters (up to 33\%); (2) Partial adopters ( 34-66\%) and (3) High adopters $(67-100 \%)$.

\section{RESULTS AND DISCUSSION}

\section{Characteristics of Layer Smallholders}

Layer farmers' characteristics are presented in Table 1. It is indicated that most of layer smallholders were males (96.67\%) only $3.33 \%$ were females. This showed that the role of women 


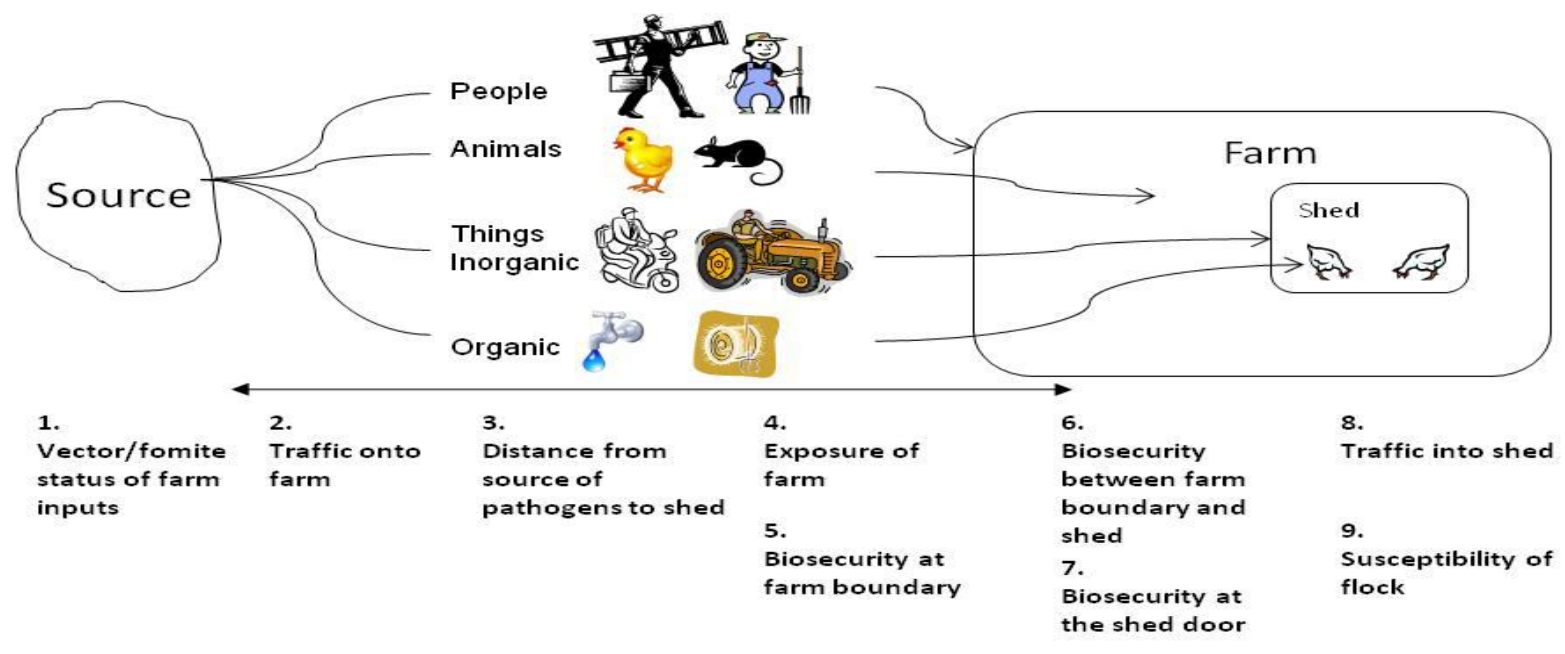

Figure 1: A model of Poultry Farm Biosecurity Showing Nine Areas where Biosecurity May be Assessed (Patrick and Jubb, 2010)

farmers in poultry raising was small.

Regarding to the age of respondents, the range of 41-55 years indicated that majority of the respondents were young $(65.0 \%)$. It can therefore be implied that the layer smallholders were middle aged and might still have energy to cope with the rigorous of layer activities. Vincent et al. (2011) stated that layer activities consisted of feeding and watering, brooding, repair in poultry house, buying and transporting chicks, collecting eggs, selling culls, and marketing.

Majority $(93.33 \%)$ of the respondents had formal education, of which $51.67 \%$ were graduated from senior high school. The result showed that the educational level of layer smallholders was fairly high in the study area, with the mean value was 10.20 years. Most respondents $(58.33 \%)$ were generally had 5-10 years of experience in raising layer, with the mean value was 8.2 years. The holding type of respondents mostly were independent $(95.0 \%)$, only $5.0 \%$ of respondents depended on company partnership who supported all of layer chicken needs, such as day old chick (DOC), feeds, vaccines, technical assistance and marketing chicken products. Table 1 also showed that most of respondents $(86.67 \%)$ was dominated by small scale farms which raised layer chicken less than 10,000 birds, with the mean value was 5.875 birds. Majority of respondents $(68.33 \%)$ had household size between 4 and 6 persons, with the mean value was 4.1 persons.

\section{Farm Biosecurity Status Score (FBSS)}

Table 2 showed that layer smallholders in Sidrap regency have a higher biosecurity score for all risk stages except biosecurity at farm gate to the shed and traffic onto the shed being 7.1 and 4.0, respectively. This finding collaborated with Patrick and Jubb (2010) research that layer smalholders in West Jawa and Bali have a higher biosecurity score for all risk stages except biosecurity at farm gate to the shed and traffic onto the shed being 9.7 and 9.4 for biosecurity at farm gate to shed in Bali and West Jawa, while traffic into shed was 4.2 and 4.1, respectively. This indicated that biosecurity at farm gate to shed and traffic onto the shed in layer smallholders in Sidrap regency shoud be enhanced.

The low level of biosecurity at farm gate to shed was evident from the following factors: (1) very few smallholders have farm gate to prevent people or animals entering the farm area; (2) few signs in use banning entry to the farm area; and (3) very few smallholders have a sanitary tub for feet washing (foot bath) before entering the poultry area. This was consistent with the findings of Nerkar et al. (2010) that layer farms in India lack of foot bath system.

The low level of biosecurity score for traffic onto the shed caused by many people was able to enter the shed and rodents. This was evident from some consumers bought eggs directly in the shed. It was known that human activities were the main route for the spread of the virus (Bleich et al., 
Table 1. Characteristics of Layer Smallholders

\begin{tabular}{|c|c|c|c|}
\hline No & Item & $\begin{array}{c}\text { Frequency } \\
\text { (person) }\end{array}$ & $\begin{array}{c}\text { Percentage } \\
(\%)\end{array}$ \\
\hline 1 & $\begin{array}{l}\text { Age (year) } \\
\quad<40 \\
41-55 \\
>55\end{array}$ & $\begin{array}{r}12 \\
39 \\
9\end{array}$ & $\begin{array}{l}20.00 \\
65.00 \\
15.00\end{array}$ \\
\hline 2 & $\begin{array}{l}\text { Gender } \\
\text { Females } \\
\text { Males }\end{array}$ & $\begin{array}{r}2 \\
58\end{array}$ & $\begin{array}{r}3.33 \\
96.67\end{array}$ \\
\hline 3 & $\begin{array}{l}\text { Educational status (year) } \\
\text { No formal education } \\
\text { Primary education } \\
\text { Secondary education } \\
\text { Tertiary education } \\
\text { Formal education }\end{array}$ & $\begin{array}{r}4 \\
9 \\
10 \\
31 \\
6\end{array}$ & $\begin{array}{r}6.67 \\
15.00 \\
16.67 \\
51.67 \\
10.00\end{array}$ \\
\hline 4 & $\begin{array}{l}\text { Experience in layer farms (year) } \\
<5 \\
5-10 \\
>10\end{array}$ & $\begin{array}{l}12 \\
35 \\
13\end{array}$ & $\begin{array}{l}20.00 \\
58.33 \\
21.67\end{array}$ \\
\hline 5 & $\begin{array}{l}\text { Holding type } \\
\text { Partnership } \\
\text { Independent }\end{array}$ & $\begin{array}{r}3 \\
57\end{array}$ & $\begin{array}{r}5.00 \\
95.00\end{array}$ \\
\hline & $\begin{array}{l}\text { Farm size (Number of birds) } \\
<10.000 \\
>10.000\end{array}$ & $\begin{array}{r}52 \\
8\end{array}$ & $\begin{array}{l}86.67 \\
13.33\end{array}$ \\
\hline 7 & $\begin{array}{l}\text { Household size (persons): } \\
\leq 3 \\
4-6\end{array}$ & $\begin{array}{l}18 \\
41\end{array}$ & $\begin{array}{r}30.0 \\
68.33\end{array}$ \\
\hline & $>6$ & 1 & 1.67 \\
\hline
\end{tabular}

2009). The other evident was rodents entered to sed. Backhans and Fellstrom (2012) argued that rodents on farms pose a danger of introducing new infections into the livestock inside, so rodent control should be considered an important measure to provide good bio-security.

Table 2 showed that overall, total farm biosecurity status score (FBSS) was 123.71. This score showed that layer smallholders achieved total score from 65 individual biosecurity indicator was 123.71 , while the maximum score was 195 (It came from 65 x 3). In other words, layer smallholders were still lack behind a good biosecurity. This finding was smaller than total FBSS of layer smallholders in Bali and West Java (Patrick and Jubb, 2009), that was 125.8 and 140.0, respectively. This comparison may motivated layer smallholders in South Sulawesi to do a better biosecurity measures through
Tabel 2. Farm Biosecurity Status Score Based on Nine Risk Stages

\begin{tabular}{lc}
\hline \multicolumn{1}{c}{ Risks } & $\begin{array}{c}\text { Biosecurity } \\
\text { scores }\end{array}$ \\
\hline Farm inputs & 17.88 \\
Traffic onto the farm & 17.12 \\
Distance to source of risk & 21.78 \\
Vulnerability of farm & 20.23 \\
Biosecurity at farm gate & 15.03 \\
Biosecurity farm gate to shed & 7.10 \\
Biosecurity at shed & 8.75 \\
Traffic onto shed & 4.00 \\
Susceptibility of layer flock & 11.82 \\
Farm Biosecurity Satus Score & 123.71 \\
(FBSS) & \\
\hline
\end{tabular}


Tabel 3 . Level of Adoption of Total Biosecurity Measures

\begin{tabular}{lccc}
\hline \multicolumn{1}{c}{ Level of Adoption } & $\begin{array}{c}\text { Number of } \\
\text { Respondents }\end{array}$ & $(\%)$ & $\begin{array}{c}\text { Mean of Adoption } \\
\text { Index }\end{array}$ \\
\hline Low adopter & 25 & 41.67 & \\
Partial adopter & 16 & 26.67 & \\
High adopter & 19 & 31.66 & 63.44 \\
Total & 60 & 100.00 & \\
\hline
\end{tabular}

voluntary adoption by farmers. Bleich et al. (2009) argued that developing and achieving adoption of biosecurity measures required a multidisciplinary and participatory approach working with producers, intermediaries, LBM traders and communities. Fraser et al. (2010) added that financial inducements or penalties to farmers could be necessary to facilitate adoption of biosecurity measures.

\section{Adoption Level of Total Biosecurity}

Table 3 showed that for all risks stage, majority of layer farmers $(41.67 \%)$ achieved a low level of biosecurity adoption. The low level of biosecurity adoption might caused by socioeconomic and technical factors. Olele and Emah (2007) found that the low level of adoption of improved fish technologies was attributed to cost of technologies, their complexities and lack of extension contact.

Comparing this results with the research has done by Susilowati et al. (2010), majority of layer smallholders in West Java (49\%) adopted high level of biosecurity measures. This indicated that layer smallholders in West Java have better biosecurity measures in their farms. East et al. (2006) and East (2007) stated that high levels of biosecurity and hygiene practices had been adopted by most chicken farms in commercial layer in Australia.

In general, the mean of adoption index which showed the total level of biosecurity measures by layer smallholders was 63.44 and categorized as a partial adopter. This mean that 63.44 of part of biosecurity measured which consisted of 65 indicators have been adopted by layer smallholders in Sidrap regency, while 36.56 part of biosecurity measures have not been adopted. This implied that if layer smallholders did not want to suffer from loss, they should motivated themselves to implement several biosecurity measures which have not been implemented. This adoption index was higher than Rahman's findings (2007) in the level adoption of pig management, which was 55.87.

\section{CONCLUSION}

In general, biosecurity adoption level based on farm biosecurity status score among layer smallholders in South Sulawesi can be classified into a partial adopter. The low level of biosecurity at farm gate and traffic onto the shed can be enhanced by layer smallholders through voluntary adoption.

\section{ACKNOWLEDGEMENT}

This study was funded by ACIAR Project AH/2006/169. The authors would like to take this opportunity to thank Dr. Ian Patrick and Dr. Tristan Jubb, who supported us to do with the research and writing of this paper.

\section{REFERENCES}

Arikunto, S. 2002. Prosedur Penelitian. Penerbit Rineka Cipta, Jakarta.

Australian Biosecurity Co-operative Research Centre. 2009. About Biosecurity: What is Biosecurity. http://www1.abere.org.au.pages/about.aspx?/ MenuID=31. Retrieved $3^{\text {rd }}$ November 2011.

Backhans, A. and Fellstrom, C. 2012. Rodents on pig and chicken farms - a potential threat to human and animal helath. Inf. Eco. Epi. 2:17093.

Bleich, E.G., P. Pagani., and N. Honhold. 2009. Progress towards practical options for improving biosecurity of small-scale poultry producers. World's Poult. Sci. J. 65(2):211216.

Dinas Peternakan Kabupaten Sidenreng Rappang. 2011. Pemda Kabupaten Sidenreng Rappang. http://www.sidenrengrappangkab.go.id/peter 
nakan.html. Retrieved February 20 ${ }^{\text {th }}, 2011$.

Dorea, F.C., R. Berghaus., C. Hofacre., and D.J. Cole. 2010. Survey of biosecurity protocols and practices adopted by growers on commercial poultry farms in Georgia, U.S.A. Avian Diseases 54(3):107-1015.

East, I., V. Kite., Daniel, S.P., and G. Garner. 2006. A cross-sectional survey of Australian chicken farms to identify risk factors associated with seropositivity to Newcastledisease virus. Preventive Vet. Med. 77(3-4): 199-214.

East, I. 2007. Adoption of biosecurity practices in the Australian poultry industries. Aust. Vet. J. 85:107-112.

Fasina, F.O., A.M. Ali., J.M. Yilma., O. Thieme., and P. Ankers. 2011. The cost-benefit of biosecurity measures on infectious disases in the Egyptian household poultry. Preventive Vet. Med. 103(2-3):178-191.

Fraser, R.W. William, N.T. Powel, L.F., and Cook, A.J.C. 2010. Reducing Campylobacter and Salmonella infection: two studies of the economic cost and attitude to adoption of onfarm biosecurity measures. Zoonoses and Public Health. 57( 7/8):e109-e115.

Iqbal, M. 2009. Controlling avian influenza infections: the challenge of the backyard poultry. J. Mol. Genet. Med. 3(1):119-120.

Julien, D and S. Thomson. 2011. Interactive methods to educate and engage poultry producers on the importance of practicing onfarm biosecurity. J. Agric. Ext. Rur. Dev. 3(8):137-140.

Msoffe, P.L.M., D. Bunn., A.P. Muhairwa., M.M.A. Mtambo., H. Mwamhehe., A. Msago., M.R.S. Miozi and C.J. Cardona. 2009. Implementing poultry vaccination and biosecurity at the village level in Tanzania: a social strategy to promote health in freerange poultry populations. Trop. Anim. Health Prod. 42(2):253-263.

Nerkar, S.C., U.B. Kashid., D.P. Shitole., and B.R. Deshmukh. 2010. Adoption of sanitary measures by layer farmers in Marathwada region of Maharashtra state. Indian J. Poult. Sci. 45(2): 206-210.
Olele, A.U.O and G. Emah. 2007. Determinants of adoption of improved fish production technologies among fish farmer in Delta States, Nigeria. J. of Fish. Inter. 2(2):147151.

Patrick, I.W. and T.F. Jubb. 2010. Comparing biosecurity in smallholder broiler and layer farms in Bali and West Java. Proceeding Towards the Adoption of Cost-Effective Biosecurity on NICPS Farms in Indonesia. Bogor-Indonesia: June 8-9, 2010, p.5-12.

Rahman, S. 2007. Adoption of improved technologies by the pig farmers of Aizawi district of Mizoram, India. Livestock Research for Rural Development Vol.19, Article \#5. Retrieved January 30, 2012, from http://www.Irrd.org/Irrd19/1/rahm19005.htm.

Satyanaraya, S.K.V.IAS., M.N. Reddy., N. Balasubramani., P. Chandrashekara., K.H. Rao and B.S. Santakki. 2008. Sustainable Livestock Development. National Institute of Agricultural Extension Management (MANAGE). Andhira Pradesh, India.

Sharma, B. 2010. Poultry production, management and bio - security measures. The Journal of Agriculture and Environment. Review Paper 11:120-124.

Susilowati, S.H., M. Iqbal and I. Patrick. 2010. The relationship between biosecurity and farm characteristics. Proceeding Towards the Adoption of Cost-Effective Biosecurity on NICPS Farms in Indonesia. Bogor-Indonesia: June 8-9, 2010, p.5-12.

Van den Ban, A.W. and H.S. Hawkins. 1999. Penyuluhan Pertanian. Penerbit Kanisius. Yogyakarta.

Vincent, N., B.K. Langat., R. Wendi and M.J. Kipsat. 2011. Gender aspect in adoption of commercial poultry production among perurban farmers in Kericho Municipality, Kenya. J. Dev. Agric. Econ. 3(7):286-301.

Zavala. 2011. Viral Respiratory Disease of Poultry: A Continuous Challenge. Poultry Disease. This paper was presented at the XVII World Veterinary Poultry Association Congress in Cancun, Mexico, August 14-18, 2011. 